\title{
Bovine Leukaemia Virus Tax Antigen Identification in Human Lymphoma Tissue: Possibility of Onco-protein Gene Transmission
}

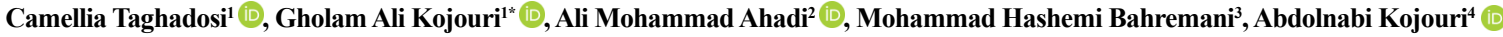

1. Department of Clinical Sciences, Faculty of Veterinary Medicine, Shahrekord University, Shahrekord, Iran.

2. Department of Genetics, Faculty of Basic Sciences, Shahrekord University, Shahrekord, Iran.

3. Laboratory of Pathology, Imam Hossein Hospital, Tehran, Iran.

4. Faculty of Medicine, International Campus of Shahid Sadoughi Medical University, Yazd, Iran.

\begin{tabular}{|l|l|}
$\begin{array}{c}\text { Use your device to scan } \\
\text { and read thearticle online }\end{array}$ & $\begin{array}{l}\text { Crtation Taghadosi C, Kojouri GA, Ahadi AM, Hashemi Bahremani M, Kojouri A. Bovine Leukaemia Virus Tax Antigen } \\
\text { Identification in Human Lymphoma Tissue: Possibility of Onco-protein Gene Transmission. Research in Molecular Medicine. } \\
\text { 2019; 7(2): 25-32. https://doi.org/10.32598/rmm.7.2.75 }\end{array}$ \\
doi https://doi.org/10.32598/rmm.7.2.75
\end{tabular}

\section{(c) (i) (8)}

Article Type:

Research Paper

Article info:

Received: 20 Jan 2019

Revised: 18 Feb 2019

Accepted: 25 Feb 2019

Keywords:

Lymphoma, Nested PCR, RTnested-PCR, Tax

\begin{abstract}
A B S T RA C T
Background: Bovine Leukaemia Virus (BLV) is the cause of Enzootic Bovine Leukosis (EBL) which belongs to retroviruses including Human T-cell leukaemia virus and simian T-lymphotropic virus. Due to this familiarity, the possibility of BLV transfer from animal production to humans may exist.

Materials and Methods: In the present study, formalin-fixed, paraffin-embedded and fresh human lymphomas tissues were used for detecting the BLV Tax genome and BLV Tax expression using nested-PCR and RT-nested-PCR.

Results: Nested-PCR evaluation showed that 9 of 41 samples contained Tax region of BLV genome, of which eight samples belonged to high grade diffuse large cell lymphoma (B-cell type). Also, the results of RT-nested-PCR showed the BLV Tax expression in 2 of 5 high grade diffuse large cell lymphoma (B-cell type) samples.

Conclusion: These findings explain the possible relation between BLV infection and the occurrence of some types of human lymphomas for the first time.
\end{abstract}

\section{Introduction}

ovine Leukaemia Virus (BLV) belongs to B the Retroviridae family and it is an agent for Enzootic Bovine Leukosis (EBL) [1]. Bovine leukosis was first reported by Leisering (1871), who described the presence of nonsuppurative nodules in enlarged spleen [2].

This virus belongs to the oncogenic retroviruses including human T-cell leukaemia virus types 1, 2, and 3 (HTLV-1, HTLV-2, and HTLV-3), and Simian T-lymphotropic Virus (STLV) [3]. These groups of retroviruses encode Tax protein, which transformed the infected cells [4].

In addition to gag, pol and env genes which are required for the synthesis of viral particle, the BLV genome contains X region, located between the envelope gene and the $3^{\prime}$ long terminal repeat ( $3^{\prime}$-LTR). This region contains some genes

\section{* Corresponding Author:}

Gholam Ali Kojouri, PhD.

Address: Department of Clinical Sciences, Faculty of Veterinary Medicine, Shahrekord University, Shahrekord, Iran.

Phone: +98 (38) 32324427

E-mail:drgholam_alikojouri@yahoo.com 
including Tax, Rex, R3, and G4 [1] that the Tax and Rex genes are involved in regulation of viral transcription [5].

The lymphoid neoplasms in human encompass a group of entities that vary widely in terms of their clinical presentation and behaviour. Others, the lymphomas, typically appear as tumour masses within either lymph nodes or other organs. Two groups of lymphomas are recognized: Non-Hodgkin's Lymphomas (NHLs) and Hodgkin lymphoma that both arise in the lymphoid tissue [6]. Unfortunately, the aetiology of most cases of NHLs is unknown, although several genetic, environmental and infectious agents have been associated with the development of these types of lymphomas [7, 8].

Milk of infected cows commonly contains the viral particles, which is the root of transmission for chimpanzees [9]. Recently, a study on 96 Australian women by Buehring et al. showed the presence of virus DNA in 41 and $80 \%$ of healthy and breast cancer women, respectively [10]. Whereas, the risk of developing leukaemia for workers of livestock farm and meat processing is controversial [9].

In the current study, we have hypothesized that BLV can be one of the infectious causes of some types of human lymphomas and the main objective of this study was, therefore to investigate and monitor the BLV Tax genome in some types of human lymphoid malignancies.

\section{Materials and Methods}

The BLV genome in viral particle is composed of RNA that changes to DNA when the virus integrates to the host cell genome as proviral DNA. Thus, proviral DNA extraction procedures were performed on paraffin-embedded tissues. Special precautions were taken to avoid contamination and all steps were carried out in separate rooms, all pipetting procedures were performed under Plexiglas boxes and rooms were pre-irradiated with ultra violet light [11].

Tissue samples

The present study was conducted on forty-one formalin-fixed, paraffin-embedded and 5 fresh human lymphoma tissues (Laboratory of Pathology, Iran Mehr Hospital and Khatamolanbia Hospital, Iran). By using sterile blades, two slices were prepared and collected in the labelled sterile microtubes. Samples of fresh tissues were also prepared and kept in liquid nitrogen.

\section{RNA extraction from paraffin-embedded tissues}

Samples of Formalin-Fixed Paraffin-Embedded (FFPE) tissues in labelled microtubes were deparaffinized by washed for $30 \mathrm{~min}$ in $1 \mathrm{ml}$ xylene and twice for 30 min with 15 min intervals in $100 \%$ ethanol and $70 \%$ ethanol, respectively at room temperature. After air drying, each of the sections was incubated with $500 \mu \mathrm{l}$ of White Cell Lysis Buffer (Wclb) (100 mM Tris-HCl [pH 7.6], $40 \mathrm{mM}$ EDTA [pH 8.0], $50 \mathrm{mM} \mathrm{NaCl}$, and $0.2 \%$ sodium dodecyl sulphate) and $3 \mu \mathrm{l}$ proteinase $\mathrm{K}$ at $55^{\circ} \mathrm{C}$ for $2 \mathrm{~h}$. In the next step, $200 \mu$ l saturated-6M $\mathrm{NaCl}$ was added to each microtube and all the samples were cooled for $15 \mathrm{~min}$ in $-20^{\circ} \mathrm{C}$. The samples were centrifuged for $15 \mathrm{~min}$ in $12000 \mathrm{~g}$ at $4^{\circ} \mathrm{C}$, the upper aqueous phase was transferred to a new tube, mixed with 1 volume of isopropanol. After centrifugation for $15 \mathrm{~min}$ in $12000 \mathrm{~g}$ at $4^{\circ} \mathrm{C}$, the upper aqueous phase was thrown away and DNA was ethanol precipitated. DNA pellet was dissolved in $30 \mathrm{ml}$ distilled water and the solution was stored at $-20^{\circ} \mathrm{C}$ for nested-PCR reaction [12].

\section{RNA extraction from fresh tissues}

For total RNA extraction from fresh samples the RNX-plus solution were used (Cinnagen, Iran, Cat. No. RN7713C). One millilitre of RNX-plus solution was added to pre-homogenized sample and incubated at room temperature for $5 \mathrm{~min}$. After that, $200 \mu \mathrm{L}$ chloroform was added and centrifuged in $12,000 \mathrm{rpm}$ at $4^{\circ} \mathrm{C}$ for $15 \mathrm{~min}$. The upper phase was separated, equal volume of cold isopropanol added to it and centrifuged in $12,000 \mathrm{rpm}$ for $15 \mathrm{~min}$. Resulting pellet was then washed via using $70 \%$ ethanol. The extracted RNA was dissolved in Diethyl Pyrocarbonate (DEPC)-treated water and stored at $70^{\circ} \mathrm{C}$.

\section{cDNA synthesis}

By using reverse transcription method, cDNA was synthesized. A mixture containing total RNA $(10 \mu \mathrm{L})$, primers $(0.5 \mu \mathrm{M}$ final concentration), and sterile DEPC solution $(1 \mu \mathrm{L})$ were incubated at $65^{\circ} \mathrm{C}$ for $5 \mathrm{~min}$. The mixture was then briefly quenched on ice and mixed with additional mixture containing $1 \mu \mathrm{L}$ of M-MLV reverse transcriptase (BIONEER, South Korea, Cat. No. E-3121-CFG), $2 \mu \mathrm{L}$ dNTP and $4 \mu \mathrm{L}$ RT reaction buffer The RT reaction was carried out at $42^{\circ} \mathrm{C}$ for $1 \mathrm{~h}$ and terminated by incubation at $70^{\circ} \mathrm{C}$ for $10 \mathrm{~min}$. Then microtubes were stored at $-20^{\circ} \mathrm{C}$ for nested-PCR reaction. 
Table 1. Primers used for PCR and nested PCR amplification of BLV proviral genome

\begin{tabular}{ccc}
\hline Primers Type & Primer & Sequences (5'-3') \\
\hline (First round PCR) & Forward (Txf) & ATGCCTGGTGCCCCCTCT \\
& Reverse (Txr) & ATTGGCATTGGTAGGGCTGG \\
(Nested PCR) & Forward (FwinTX) & GAAAGGATCGACACCACGCTC \\
& Reverse (RewinTX) & ATTGGCATTGGTAGGGCTGG \\
\hline
\end{tabular}

\section{Primers design}

The primers for both nested-PCR and RT-nested-PCR were designed according to sequence reference number EF600696 on NCBI GenBank (Table 1).

\section{Nested-PCR assay}

Polymerase chain reaction was performed using $3 \mu \mathrm{L}$ of cDNA with 1 Unit per reaction of Taq DNA polymerases (Cinnagen Co. Cat. No. TA8109C) $(500 \mathrm{U} / \mu \mathrm{L}), 50$ $\mathrm{mM}$ of $\mathrm{MgCl} 2,2.5 \mu \mathrm{L}$ of PCR buffer (10X), $0.5 \mu \mathrm{L}$ of dNTP, $0.5 \mu \mathrm{L}$ of each primer $(20 \mathrm{pmol} / \mathrm{L})$, and $18.1 \mu \mathrm{L}$ of sterile double distilled water.

PCR program was planned using thermocycler (Techne TC-512) as follows: a heated lid $\left(105^{\circ} \mathrm{C}\right.$ for $\left.4 \mathrm{~min}\right)$ and after that the reaction mixtures were subjected to 40 cycles of amplification by using the following program: $\left(94^{\circ} \mathrm{C}\right.$ for 30 s, $58^{\circ} \mathrm{C}$ for $30 \mathrm{~s}$, and $72^{\circ} \mathrm{C}$ for $30 \mathrm{~s}$ ); This was followed by a final extension step at $72^{\circ} \mathrm{C}$ for $5 \mathrm{~min}$. For nested PCR, 0.5 $\mu 1$ of the first PCR product was amplified using the same reaction conditions that were described previously.

\section{Analysis of amplified cDNA}

A total of $5 \mu$ l of each PCR product was mixed with 1 $\mu 16$ X loading buffer (Fermantes Co. Cat. No. \#R0611) and was subjected to $8 \%$ acrylamide gel electrophoresis in $1 \mathrm{X}$ TBE buffer (10.8 gr Tris-acetate, $4 \mathrm{ml}$ EDTA, 5.5 gr Boric acid dissolved in $1000 \mathrm{ml}$ distilled water) for 80 $\mathrm{min}$ at $90 \mathrm{~V}$. Silver staining protocol was carried out for detection of PCR products in gel. In order to confirm the PCR conditions, $20 \mu \mathrm{L}$ of PCR products was applied for sequencing by Applied Biosystems 3100 ABI (Macrogen Co. Korea).

\section{Analytical procedure}

Data were analysed using SigmaStat V. 3.1 program and the descriptive statistics and percentages were reported.

\section{Results}

Outer and inner primers (Txf,Txr and FwinTX, RewinTX) were used for both generated products of nestedPCR and RT-nested-PCR with the calculated size of a 220 bp (Figure 1 and Figure 2). The mentioned size was estimated according to the size of positive control (pure cDNA of cultured virus). No products were generated with negative control.

Among forty-one human lymphoid paraffinized tissue specimens, 9 of them and among 5 human lymphoid fresh tissue specimens, 2 of them were positive for BLV

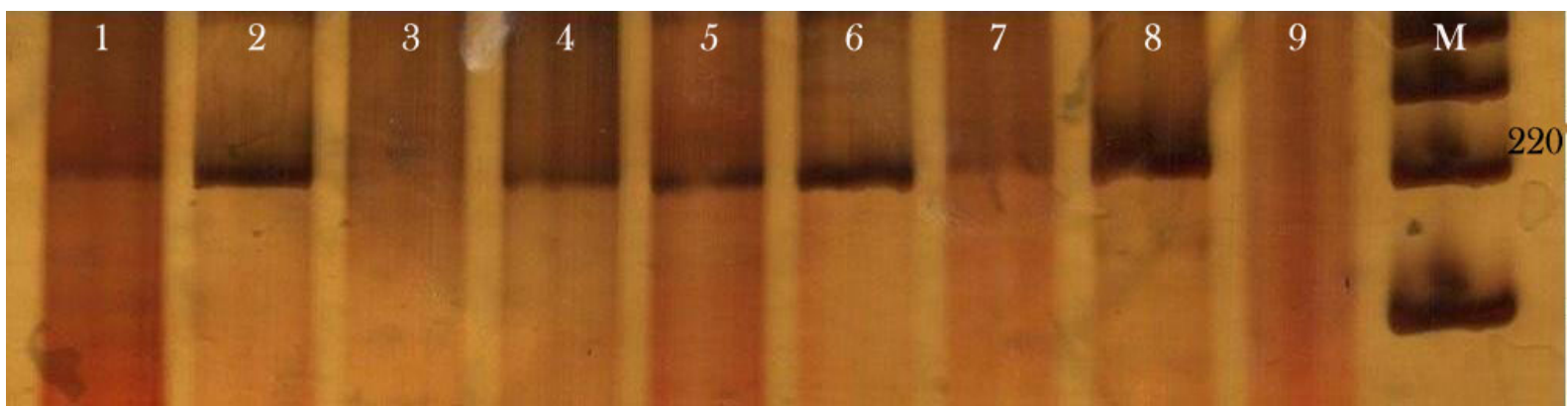

grmm

Figure 1. Nested PCR results (Acrylamide gel, Silver staining)

Lane M, molecular mass marker; lane 9 and 8 represent negative control (no template cDNA) and positive control, respectively lanes 1, 2, 4, 5, 6, and 7 positive samples; lane 3 negative sample 


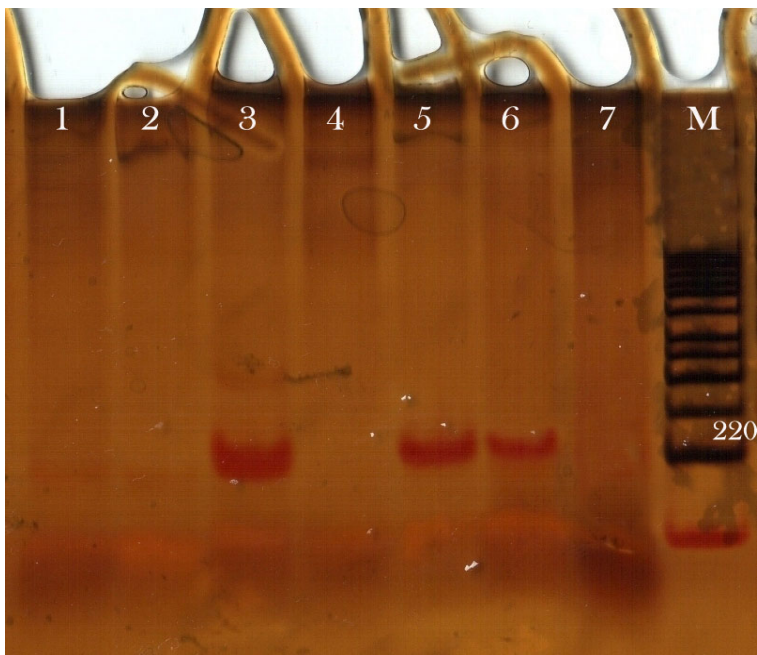

क्रmm

Figure 2. RT-nested PCR results (Acrylamide gel, Silver staining)

Lane M, molecular mass marker; lane 7 and lane 6 represent negative control (no template cDNA) and positive control, respectively; lanes 3 and 5 positive samples; lanes 1, 2, and 4 negative samples

proviral DNA using nested PCR and RT-nested-PCR, respectively (Table 2 and Table 3 ). These lymphoid tissues were obtained from lymph nodes of different parts of the body. Pathological diagnosis of these infected tissues had shown different types of lymphoid neoplasms. Among the presented types of lymphomas and from 9 positive paraffinized samples, 8 blocks with the relative frequency of $19.51 \%$, and 1 block with the relative frequency of $2.44 \%$ belonged to high grade dif- fuse large B-cell lymphoma and Burkitt's lymphoma, respectively. Also, from 5 fresh samples, 2 with relative frequency of $40 \%$ belonged to high grade diffuse large B-cell lymphoma.

\section{Discussion}

It has been estimated that twenty percent of human cancer is related to viral infection. Viral oncogenic abilities are related firstly to the generation of genomic instability and secondly to the increase in the rate of cell proliferation. Viruses also resist to apoptosis and alter the DNA repair mechanisms which finally cause the cell polarity changes and often alter the antiviral immune response [8]. Viruses may induce cancer via causing immunosuppression, chronic inflammation and chronic antigenic stimulation.

Furthermore, International Agency for Research on Cancer (IARC) classified the Epstein Barr Virus (EBV), Kaposi's Sarcoma-associated Herpesvirus (KSHV), Human High risk Papillomaviruses (HPV), Merkel Cell Polyomavirus (MCPV), Hepatitis B Virus (HBV), Hepatitis C Virus (HCV) and Human T-cell Lymphotropic Virus type 1 (HTLV1) as type 1 carcinogenic agents. 8 In this regard, it is possible that other viruses like BLV may have a role in human cancers. For the past three decades, BLV has not been regarded as a threat to humans, until Lawson et al. announced that bovine leukaemia virus gene sequences have been found by Giovanna et al. Buehring et al. and Buehring et al. in human breast cancer [10, 13-16].

Table 2. Positive specimens for BLV proviral DNA in paraffin-embedded human samples with lymphoma

\begin{tabular}{ccccc}
\hline Sample No. & Histopathological Diagnosis & Sampling Location & Age/Sex & Nested-PCR Results \\
\hline 1 & Low grade diffuse small cell lymphoma, B-cell type & neck & $60 / \mathrm{F}$ & - \\
\hline 2 & Peripheral T-cell lymphoma & neck & $72 / \mathrm{M}$ & - \\
\hline 3 & Mantle cell lymphoma & post auricular & $54 / \mathrm{M}$ & - \\
\hline 4 & Follicular lymphoma & neck & $37 / \mathrm{F}$ & - \\
\hline 5 & Low grade diffuse small cell lymphoma, B-cell type & pelvis & $23 / \mathrm{F}$ & - \\
\hline 6 & Low grade diffuse small cell lymphoma, B-cell type & neck & $68 / \mathrm{F}$ & - \\
\hline 7 & Peripheral T-cell lymphoma & bone marrow & $45 / \mathrm{F}$ & - \\
\hline 8 & Lymphoblastic lymphoma, T-cell type & neck & $31 / \mathrm{M}$ & - \\
\hline 10 & Large cell anaplastic lymphoma, T-cell type, high grade & neck & $39 / \mathrm{M}$ & - \\
\hline
\end{tabular}




\begin{tabular}{|c|c|c|c|c|}
\hline Sample No. & Histopathological Diagnosis & Sampling Location & Age/Sex & Nested-PCR Results \\
\hline 11 & Burkitt's lymphoma & inguinal canal & $43 / F$ & + \\
\hline 12 & High grade diffuse large cell lymphoma, B-cell type & Gastro-intestine & $40 / F$ & - \\
\hline 13 & Low grade diffuse small cell lymphoma, B-cell type & bone marrow & $45 / \mathrm{M}$ & - \\
\hline 14 & High grade diffuse large cell lymphoma, B-cell type & mediastinum & $16 / \mathrm{M}$ & - \\
\hline 15 & High grade diffuse large cell lymphoma, B-cell type & neck & $71 / F$ & - \\
\hline 16 & Peripheral T-cell lymphoma & neck & $35 / \mathrm{M}$ & - \\
\hline 17 & low grade small cell lymphoma, B-cell type & axillary lymph node & $72 / \mathrm{M}$ & - \\
\hline 18 & High grade diffuse large cell lymphoma, morphologically B-cell type & tonsil & $66 / F$ & - \\
\hline 19 & High grade diffuse large cell lymphoma, B-cell type & inguinal canal & $52 / F$ & + \\
\hline 20 & High grade diffuse large cell lymphoma, B-cell type & axillary lymph node & $84 / \mathrm{M}$ & + \\
\hline 21 & Lymphoblastic lymphoma, T-cell type & neck & 24/M & - \\
\hline 22 & High grade diffuse large cell lymphoma, B-cell type & gastrointestine & $71 / F$ & + \\
\hline 23 & High grade diffuse large cell lymphoma, B-cell type & tonsil & $60 / \mathrm{M}$ & + \\
\hline 24 & High grade diffuse large cell lymphoma, B-cell type & neck & $75 / F$ & + \\
\hline 25 & High grade malignant lymphoma, B-cell type & neck & $71 / \mathrm{M}$ & + \\
\hline 26 & High grade diffuse large cell lymphoma, B-cell type & tonsil & $76 / \mathrm{M}$ & + \\
\hline 27 & High grade malignant lymphoma, diffuse large B cell type & $\begin{array}{l}\text { supraclavicular } \\
\text { lymph node }\end{array}$ & $69 / \mathrm{M}$ & + \\
\hline 28 & Small round cell tumor consistent with low grade B-cell lymphoma & mediastin & $67 / \mathrm{M}$ & - \\
\hline 29 & low grade small cell lymphoma, B-cell type & inguinal canal & $63 / \mathrm{M}$ & - \\
\hline 30 & Lymphoblastic lymphoma, T-cell type & Large intestine & $43 / \mathrm{M}$ & - \\
\hline 31 & low grade diffuse small cell lymphoma, B-cell type & Neck & $69 / F$ & - \\
\hline 32 & low grade diffuse small cell lymphoma, B-cell type & Neck & $59 / F$ & - \\
\hline 33 & Mantle cell lymphoma & spleen & $76 / F$ & - \\
\hline 34 & Large B-cell lymphoma, lymphomatoid granulomatosis & kidney & $27 / F$ & - \\
\hline 35 & Lymphoblastic lymphoma, T-cell type & neck & $29 / F$ & - \\
\hline 36 & low grade diffuse small cell lymphoma, B-cell type & - & $39 / F$ & - \\
\hline 37 & low grade small cell lymphoma, B-cell type & neck & $33 / \mathrm{M}$ & - \\
\hline 38 & Peripheral T-cell lymphoma & neck & $52 / \mathrm{M}$ & - \\
\hline 39 & Lymphoblastic lymphoma, T-cell type & bone marrow & 23/M & - \\
\hline 40 & $\begin{array}{l}\text { Diffuse small lymphocytic lymphoma, morphologically B-cell type, low } \\
\text { grade }\end{array}$ & axillary lymph node & $78 / F$ & - \\
\hline 41 & Anaplastic large cell lymphoma, high grade, T-cell type & axillary lymph node & $28 / \mathrm{M}$ & - \\
\hline
\end{tabular}

F: Female; M: Male 
Table 3. Positive specimens for BLV proviral DNA in fresh human samples with lymphoma

\begin{tabular}{ccccc}
\hline $\begin{array}{c}\text { Sample } \\
\text { No. }\end{array}$ & Histopathological Diagnosis & Sampling Location & Age/Sex & RT-nested-PCR Results \\
\hline 1 & High grade malignant lymphoma, diffuse large B cell type & Supraclavicular lymph node & $69 / \mathrm{M}$ & + \\
\hline 2 & Peripheral T-cell lymphoma & Bone marrow & - & - \\
\hline 3 & Lymphoblastic lymphoma, T-cell type & Neck & $50 / \mathrm{F}$ & - \\
\hline 4 & Low-grade B-cell lymphoma & Mediastinum & $67 / \mathrm{M}$ & + \\
\hline 5 & Non-Hodgkin's lymphoma, Diffuse large B-cell type; High grade & Neck & $75 / \mathrm{F}$ & + \\
\hline F: Female; M: Male & & &
\end{tabular}

A human serological survey by using immunoblot test, showed the presence of BLV antibody in $74 \%$ of samples, which could be a response to BLV antigens in heat-treated milk or meat and direct contact with cattle [9]. This indicates that people are exposed to antigens derived from BLV. The potential human health hazards associated with BLV have been a constant concern of the meat and dairy industries [17, 18]. Cohort and casecontrol studies suggest that higher intake of meats and dietary fat increased the risk of NHLs [19]. The fifth most common systemic human cancer is Lymphoma, in which Diffuse Large B-cell Lymphoma (DLBL) is the most common subtype [6].

Our study was performed on paraffinized and fresh lymphoid tissues of NHLs patients using nested-PCR and RT-nested PCR for detection of BLV Tax genome. Results showed a relative frequency of $21.95 \%$ and $40 \%$ BLV genome in paraffinized and fresh samples, respectively. Previously, Mannetje et al. showed an elevated non-Hodgkin's lymphoma (NHLs) risk among meat processors but none of these studies has shown any direct correlation between the observed malignancies and BLV infections in the cattle present on the farm [20]. Recently, some researchers established a linked between the presence of BLV genome in humans and breast cancer but the current study went a bit further and for the first time confirmed the presence of Tax genome in some types of human lymphomas [10, 21]. The presence of BLV Tax genome was confirmed by nested-PCR assay in mostly high-grade diffuse B-cell type lymphoma ( 8 of 41 samples), Burkitt's lymphoma (1 of 41 samples) and one type of lymphoma in RT-nested-PCR assay. Highgrade diffuse B-cell type lymphoma (2 of 5 fresh samples) was also detected. Furthermore, the BLV Tax gene was confirmed by sequencing the nested-PCR products of positive samples.

Tax region of BLV disrupts the regulation of cellular gene expression and alters cellular processing, DNA replication, DNA repair and apoptosis, leading to immortalization, transformation and leukemogenesis [22] Merimi et al. suggested that silencing is critical for tumour progression and identified two distinct mechanisms involved in the complete suppression of virus and Tax expression in the BLV-injected sheep [23]. Usui et al. also showed that vaccination with BLV Tax-coding DNA induced protective effect against BLV in the early phase of infection [24].

These findings show the BLV's direct involvement in formation of some types of NHLs for the first time. The results of present study along with other studies indicate the possibility of BLV transmission to humans and as a result the necessity for veterinary authorities to encourage BLV eradication programs in dairy industry.

\section{Conclusion}

The research proved that the Tax region genome of Bovine leukemia virus exists in two types of human lymphomas (DLBL and BLs). So, BLV is associated with human lymphoma and bovine leukosis should be eradicated from dairy farms.

\section{Ethical considerations}

\section{Compliance with ethical guidelines}

All ethical principles were considered in the study.

Funding

This research did not receive any specific grant from funding agencies in the public, commercial, or not-forprofit sectors.

\section{Authors contribution}


Data collection, PCR analysis, and writing: All authors; Design, analysis: Gholam Ali Kojouri; PCR performing: Gholam Ali Kojouri; Revisision: Abdolnabi Kojouri.

\section{Conflict of interest}

The authors declared no conflict of interest.

\section{Acknowledgements}

The authors would like to thank Dr. Eetemad Moghadam and Mrs. Anbardar, (Pathology Lab), Dr. Hasan Momtaz (Azad University of Shahrekord, Iran) and Research Institute of Animal Embryo Technology (Shahrekord University, Iran) for their invaluable advice.

\section{References}

[1] Rola-Loszczak M, Pluta A, Olech M, Donnik I, Petropavlovskiy M, Gerilovych A, et al. The molecular characterization of bovine leukaemia virus isolates from eastern europe and siberia and its impact on phylogeny. PLoS One. 2013; 8(3):e58705. [DOI:10.1371/journal.pone.0058705] [PMID] [PMCID]

[2] Gillet N, Florins A, Boxus M. Burteau C, Nigro A, Vandermeers $\mathrm{F}$, et al. Mechanisms of leukemogenesis induced by bovine leukemia virus: prospects for novel anti-retroviral therapies in human. J Retrovirol. 2007; 4(18):1-32. [DOI:10.1186/1742-4690-4-18] [PMID] [PMCID]

[3] Clattini S, Chevalier SA, Duprez R, Afonso P, Froment A, Gessain A, et al. Human T-Cell Lymphotropic virus type 3: Complete nucleotide sequence and characterization of the human Tax3 protein. J Virol. 2006; 80(19):9876-88. [DOI:10.1128/JVI.00799-06] [PMID] [PMCID]

[4] Waldele K, Silbermann K, Schneider G, Ruckes T, Cullen BR, Grassmann R. Requirement of the Human T-cell Leukemia Virus (HTLV-1) tax-stimulated HIAP-1 gene for the survival of transformed lymphocytes. Blood. 2006; 107:4491-9. [DOI:10.1182/blood-2005-08-3138] [PMID]

[5] Zhao X, Buehring G. Natural genetic variations in bovine leukemia virus envelope gene: Possible effects of selection and escape. J Virol. 2007; 366(1):150-65. [DOI:10.1016/j.virol.2007.03.058] [PMID]

[6] Armitage JO. How I treat patients with diffuse large Bcell lymphoma. Blood. 2007; 110(1):29-36. [DOI:10.1182/ blood-2007-01-041871] [PMID]

[7] Hjalgrim, H. On the aetiology of hodgkin lymphoma. Dan Med J. 2012; 59(7):B4485.

[8] Morales-Sánchez A, Fuentes-Pananá EM. Human viruses and cancer. Viruses. 2014; 6(10):4047-9. [DOI:10.3390/ v6104047] [PMID] [PMCID]

[9] Constable PD, Hinchcliff KW, Done SH, Grünberg W. Veterinary medicine: A textbook of the diseases of cattle, horses, sheep, pigs and goats, $11^{\text {th }}$ edition. St. Louis: Elsevier; 2017.
[10] Buehring GC, Shen H, Schwartz DA, Lawson JS. Bovine leukaemia virus linked to breast cancer in Australian women and identified before breast cancer development. PLoS One. 2017; 12(6):e0179367. [DOI:10.1371/journal.pone.0179367] [PMID] [PMCID]

[11] Klener P, Szynal M, Cleuter Y, Merimi M, Duvillier H, Lallemand F, et al. Insights into gene expression changes impacting B-Cell transformation: Cross-species microarray analysis of Bovine Leukemia Virus Tax-responsive genes in ovine B Cells. J Virol. 2006; 80(4):1922-38. [DOI:10.1128/ JVI.80.4.1922-1938.2006] [PMID] [PMCID]

[12] Abrahamsen HN, Steiniche T, Nexo EJ, Hamilton-Dutoit S, Sorensen B. Towards quantitative mRNA analysis in paraffin- embedded tissues using real-time reverse transcriptasepolymerase chain reaction; A methodological study on lymph nodes from melanoma patients. J Mol Diagn. 2003; 5(1):34-41. [DOI:10.1016/S1525-1578(10)60449-7]

[13] Lawson JS, Salmons B, Glenn WK. Oncogenic viruses and breast cancer: Mouse Mammary Tumour virus (MMTv), Bovine Leukaemia virus (BLv), Human Papilloma virus $(\mathrm{HPv})$, and epstein-Barr virus (eBv). Front Oncol. 2018; 8:118. [DOI:10.3389/fonc.2018.00001] [PMID] [PMCID]

[14] Giovanna M, Ulloa JC, Uribe AM, Gutierre MF. Bovine leukemia virus gene segment detected in human breast tissue. Open J Med Microbiol. 2013; 3(1):84-90. [DOI:10.4236/ ojmm.2013.31013]

[15] Buehring GC, Shen HM, Jensen HM, Choi KY, Sun D, Nuovo G. Bovine leukaemia virus DNA in human breast tissue. Emerg Infect Dis. 2014; 20(5):772-82. [DOI:10.3201/ eid2005.131298] [PMID] [PMCID]

[16] Buehring GC, Shen HM, Jensen HM, Jin DL, Hudes M, Block G. Exposure to bovine leukaemia virus is associated with breast cancer: A case-control study. PLoS One. 2015; 10 (9):e0134304. [DOI:10.1371/journal.pone.0134304] [PMID] [PMCID]

[17] Matsumoto M, Ishikawa S, Nakamura Y, Kayaba K, Kajii E. Consumption of dairy products and cancer risks. J Epidemio. 2007; 17(2):1-7. [DOI:10.2188/jea.17.38] [PMID]

[18] Johnson E. Assessing the role of transmissible agents in human disease by studying meat workers. Cell Sci. 2005; 2(1):114.

[19] Devita VT, Hellman V, Rosenberg S. Cancer principals. Philadelphia: Lippincott Williams \& Wilkins; 2005.

[20] Mannetje AT, Dryson E, Walls C, McLean D, McKenzie $\mathrm{F}$, Maule $\mathrm{M}$, et al. High risk occupations for non-Hodgkin's lymphoma in New Zealand: Case-control study. Occup Environ Med. 2008; 65(5):354-363. [DOI:10.1136/ oem.2007.035014] [PMID]

[21] Baltzell KA, Shen HM, Krishnamurty S, Sison JD, Nuovo GJ, Buehring GC. Bovine leukaemia virus linked to breast cancer but not coinfection with human papillomavirus: Case-control study of women in Texas. Cancer. 2018; 124(7):1342-9. [DOI:10.1002/cncr.31169] [PMID]

[22] Wycuff DR, Marriott SJ. The HTLV-1 Tax oncoprotein: Hyper-tasking at the molecular level. Front Biosci. 2005; 10: 620-42. [DOI:10.2741/1558] [PMID]

[23] Merimi M, Klener P, Szynal M, Cleuter Y, Bagnis C, Kerkhofs $\mathrm{P}$, et al. Complete suppression of viral gene expression 
is associated with the onset and progression of lymphoid malignancy: Observations in Bovine leukemia virus-infected sheep. J Retrovirol. 2007; 4(51):1-9. [DOI:10.1186/1742 4690-4-51] [PMID] [PMCID]

[24] Usui T, Konnai S, Tajima S, Watarai S, Aida Y, Ohashi K, et al. Protective effects of vaccination with Bovine Leukemia Virus (BLV) Tax DNA against BLV infection in sheep. J Vet Med Sci. 2003; 65(11):1201-5. [DOI:10.1292/jvms.65.1201] [PMID] 